\title{
СТРАТЕГІЯ ВІДНОВЛЕННЯ САМОЕФЕКТИВНОСТІ ОСОБИСТОСТІ ПРИ ПЕРЕЖИВАННІ ВТРАТИ
}

Відновлення самоефективності визначено як стратегічно важливий напрям у процесі соціально-психологічної реабілітації. Розроблено стратегію відновлення самоефективності особистості при переживанні втрати, описано три послідовні етапи роботи в межах цієї стратегії: діагностичний, організаційний, технологічний. Для діагностичного етапу сформульовано такі завдання: визначення рівня самоефективності та прийняття втрати, з'ясування зон ураження внаслідок переживання втрати, виявлення внутрішніх і зовнішніх бар'єрів у процесі відновлення самоефективності та оцінювання системи ресурсів особистості. До завдань організаційного етапу віднесено розроблення індивідуального плану роботи та рекомендацій щодо відновлення самоефективності особистості, що грунтуються на результатах діагностичного оцінювання та виборі загальної стратегії роботи: ідеться про стимулювання співпраці, залучення спеціаліста (психолога, соціального працівника), який має запропонувати систему реабілітаційних заходів, а також про застосування елементів соціальнопсихологічної підтримки. У межах технологічного етапу, що презентує безпосередньо способи реабілітаційних дій, розроблено технології відновлення самоефективності особистості при переживанні втрати: технологію прийняття втрати, технологію локалізації причини втрати життєвих ресурсів особистості та медійні технології. Запропоновано такі способи відновлення самоефективності особистості: прийняття втрати, актуалізація найвищої цінності шляхом набуття глибинного сенсу страждання, прийняття власних негативних станів як особистісних ресурсів, дихальні і релаксаційні техніки, тілесні практики, реконструкція наявних смислів або побудова нових, активація спогадів про реальний успішний досвід протистояння труднощам, моделювання яскравих образів успіху, опосередковане переживання успіху, мотивувальне словесне переконування, визначення рівня домагань людини, верифікація наявних $\mathrm{i}$ потенційних ресурсів, наративні практики.

Ключові слова: переживання втрати, смерть, зони ураження, ресурси особистості, самоефективність, стратегія відновлення.

\section{K. V. Myronchak}

\section{THE STRATEGY OF PERSON'S SELF-EFFICACY RESTORATION WHILE EXPERIENCING A LOSS}

The self-efficacy restoration is defined as a strategically important direction in the process of socio-psychological rehabilitation. It is developed the strategy of self-efficacy personal restoration while experiencing a loss; there are described the three consecutive stages of work according to this strategy: diagnostic, organizational, and technological. For the diagnostic stage, the following tasks are identified: determination of self-efficacy level of and acceptance of a loss; defining of the damaged areas as a result of the loss experience; determination of internal and external barriers in the process of self-efficacy restoration, and evaluation of personal 
resources' system. As the part of an organizational stage it is concerned the development of an individual work plan and the recommendations for self-efficacy restoring which are based on the results of diagnostic evaluation and the choice of a general strategy of work: cooperation stimulation, specialist's (psychologist's, social worker's) involvement into construction of rehabilitation measures system, application of elements of socio-psychological support. As the part of the technological stage which represents directly the methods of rehabilitation, the technologies of self-efficacy recovery in the event of loss are developed: technology of loss acceptance, technology of localization of the cause of personal life resources' loss, and media technologies. The following ways of personal self-efficacy restoring are proposed: acceptance of loss, actualization of the highest value through the acquisition of the suffering's deep sense, acceptance of own negative states as personal resources, breathing and relaxation techniques, body practices, reconstruction of existing meanings or construction of the new ones, activation of memories of a real successful experience in difficulties' confronting, modelling of success images, mediated experiencing of success, motivating verbal persuasion, determination of the demands' level of a person, verification of actual and potential resources, narrative practices.

Key words: experience of loss, death, damaged areas, personal resources, self-efficacy, restoration strategy.

Постановка проблеми. 3 огляду на часто повторювані соціальнополітичні кризи в нашому суспільстві і тривалість періодів хронічного їх загострення можна, без сумніву, нинішній час назвати часом глобальних і множинних втрат - як суспільних, так і індивідуальних. Жоден людський досвід не можна уявити без втрат, адже вони є безперервним і генетично обумовленим досвідом життя. Однак такий досвід через неможливість вчасно і грунтовно його пережити може порушувати цілісність життєвої системи особистості і зруйнувати зрештою їі відчуття повноти існування. Після події втрати виникає тимчасове відчуття спустошеності, яке за умови пролонгованої дії та браку конструктивних копінгів може призвести до психосоматизації, депресії, зниження толерантності до стресу і, відповідно, зниження загального рівня самоефективності особистості - здатності адаптивно діяти в нових умовах, успішно і конструктивно розв'язувати посталі проблеми [1]. Відновлення самоефективності особистості в складний період переживання втрати є важливим завданням у процесі соціально-психологічної реабілітації особистості [2; 3], оскільки від цього залежатимуть процеси подолання людиною наслідків події втрати, інтеграції та відновлення ресурсних станів особистості задля підвищення загального рівня якості iі життя.

Аналіз останніх досліджень і публікацій, виокремлення невирішених частин загальної проблеми. Більшість психологічних досліджень втрати пов'язані зі смертю близької людини, із психологічними наслідками втрати, зокрема 3 переживанням страждань, болю, горя, скорботи, відчуття внутрішньої спустошеності та самотності 
(Д. Боулбі, С. Бохнер, А. Лорі, Р. А. Неймеєр, С. Паркес, Х. Г. Прігерсон, Д. Хелл, Н. Хоган). Однак частина дослідників обстоює протилежну думку, пов'язуючи 3 переживанням втрати можливість особистісних позитивних перетворень у життєвому досвіді людини [4; 5]. Так, наприклад, втрату за умови належного їі опрацювання можна розглядати як можливість особистісного зростання (А. Ленгле, I. Ялом, L. G. Calhoun, R. G. Tedeschi).

Що ж стосується досліджень самоефективності, то в психологічній науці означену тему досить активно почали розробляти в другій половині XX століття. Наразі вона представлена в науковому доробку дослідників як психічна здатність (Т. Гордєєва, Ф. Паджарес), як психічне утворення (Д. Кенрік, Д. Майєрс), як інтегральна характеристика самосвідомості особистості (І. Брунова-Калісецька, В. Ромек). Але найбільш концептуалізовано підійшов до цього поняття А. Бандура, який запропонував розглядати самоеефективність як усвідомлену здатність людини долати складні ситуації в житті, що позитивно впливає на ефективність ії діяльності і функціонування у світі в цілому [6]. Згідно 3 теорією А. Бандури самоефективність є результатом взаємопов'язаних процесів - поведінки людини, впливу оточення й особистісних чинників (віри, очікувань, самосприйняття, пізнання, прогнозування майбутнього, здатності до соціального навчання тощо) [7]. У гуманістичній психології (К. Роджерс, В. Франкл) здатність до самоефективності розглядають як ресурс для особистісного зростання, самоповаги, самоактуалізації та самоздійснення. Т. М. Титаренко визначає самоефективність як окремий, важливий “критерій відновлення психологічного здоров'я - можливість підтримання й оновлення продуктивності особистості, її здатності до самореалізації, креативного ставлення до власного життя" [3], який становить самостійний вектор реабілітаційної роботи з відновлення самоефективності особистості.

Мета статті: визначити основні етапи побудови стратегії, спрямовані на відновлення самоефективності особистості при переживанні втрати.

Виклад основного матеріалу дослідження. Оскільки кожна втрата тягне за собою помітне зниження рівня самоефективності, ми поставили перед собою такі завдання: знаходження оптимальних способів виходу особистості з депресивних станів, пошук і активація іiі індивідуально-особистісних ресурсів, можливостей трансформації негативних станів і травматичного досвіду в позитив, підвищення адаптивності особистості в нових умовах існування.

3 огляду на вищезазначені завдання було розроблено трьохетапну стратегію відновлення самоефективності при переживанні втрати.

Діагностичний етап. У межах цього етапу поєднуються такі дослідницькі процедури: визначення рівня самоефективності та прий- 
няття втрати; з'ясування зон уражень унаслідок переживання втрати; виявлення внутрішніх і зовнішніх бар'єрів (перешкод), що гальмують процес проживання втрати та відновлення самоефективності; оцінювання системи ресурсів особистості (ті, що були втрачені, наявні та потенційні або актуалізовані в нових умовах).

Спосіб реалізації діагностичного етапу. Під час проведення напівструктурованого інтерв'ю респондентові пропонується блок запитань, щоб прояснити особливості переживання ним втрати: Чи були у Вашому житті ситуації, коли Ви переживали втрату (відчуття порожнечі)? Що це були за ситуації? Що Ви відчували при цьому? Яке було у Вас самопочуття? Як довго Ви переживали цей стан? Які виникали у Вас думки? Як ця подія вплинула особисто на Вас, Ваше життя, на Ваші погляди і ставлення до світу, до себе, до життя?

Наступний блок запитань спрямований на те, щоб з'ясувати особливості самоефективності особистості: Що Ви робили, коли це сталося? Як Ви справилися $з$ цією ситуацією? Що Вам допомагало? Що Вас підтримувало в цій ситуації? Що додавало Вам сили в цій ситуації? Що заважало Вам бути ефективним і впевненим у собі? Що найбільше підриває Вашу віру в себе? Що змушує Вас сумніватися в собі? Що чи хто був для Вас ресурсом, підтримкою, опорою? Що, на Вашу думку, допомогло б Вам справитися 3 цією ситуацією краще? Що б Вам хотілося розвинути в собі, аби почуватися більш упевнено?

Організаційний етап. Цей етап потребує розроблення індивідуального плану роботи та рекомендацій щодо відновлення самоефективності особистості залежно від контексту переживання втрати. Від результатів діагностичного етапу залежить подальший вибір стратегії роботи. Це може бути або стимулювання співпраці та залучення до цього процесу спеціаліста (психолога, соціального працівника), щоб вибудувати систему необхідних реабілітаційних заходів, або ж застосування лише елементів соціально-психологічної підтримки для активації власних ресурсів самодопомоги людини при переживанні нею втрати.

Технологічний етап. Технології відновлення самоефективності особистості при переживанні втрати - це способи реабілітаційних дій щодо впровадження системи заходів 3 метою досягнення позитивного результату.

Технологія відновлення самоефективності особистості через прийняття втрати. Більшість людей (близько 80\%) мають ресурс для самовідновлення. Різниця лише в термінах і способах самодопомоги. Однак якщо ситуація втрати має сильний, наростаючий травматичний ефект, з яким особистість не може впоратися самостійно, то на цьому етапі доцільно залучити спеціаліста, який допоможе пройти всі етапи проживання травми - від тотального заперечення до прийняття. Більшість відомих усім етапів переживання втрати, за Е. Кюблер-Росс, люди 
проходять самостійно, без допомоги спеціалістів. Однак найважчий етап 3-поміж них, до якого доходять далеко не всі, $є$ саме прийняття. Цей етап не можна інтелектуально зімітувати (коли людина розуміє i заявляє, що прийняла втрату, але у внутрішньому досвіді емоційного ії проживання не відбулося). Така гра в прийняття може серйозно перешкоджати відновленню особистості, гальмувати процес. Критерієм успішного проходження цього етапу є якісні зміни в самовідчутті особистості, що супроводжуються емоційним полегшенням, глибинним осмисленням, відчуттям звільнення від тягаря, почуттям вдячності і бажанням рухатися далі.

Способи роботи (психологічний інструментарій) залежатимуть від того, у межах якої терапевтичної парадигми (гештальттерапія, екзистенційна терапія, когнітивно-поведінкова або клієнт-центрована терапія) працює спеціаліст. Хоча способи досягнення мети можуть різнитися, важливим буде кінцевий результат терапії - прийняття втрати, примирення з нею, що дасть змогу послабити травматичну домінанту $\mathrm{i}$ налаштувати людину на реабілітаційний процес.

Технологія відновлення самоефективності через локалізацію причини втрати життєвих ресурсів особистості. Під локалізацією мається на увазі намагання чітко визначити джерело проблеми і не допустити поширення іiі руйнівної дії на особистість. Визначивши джерело послаблення життєвого тонусу особистості, значно легше працювати над відновленням іï втрачених ресурсів. Така прицільність дає змогу виграти в часі, адже ми не генералізуємо проблему, а зосереджуємо наші зусилля на конкретній сфері.

Виявлені нами основні причини втрати життєвих ресурсів вказують на основні зони ураження, що потребують відновлення. Однією iз зон ураження стає ціннісно-смислова структура особистості. Те, що було досі смисловою опорою і фундаментом для побудови основних життєвих стратегій особистості, видається тепер хитким і ненадійним. На руїнах ілюзій про стабільність і прогнозованість життя у людини 3'являються численні сумніви, побоювання, розгубленість, тривожні очікування нових втрат. Ураження може стосуватися повністю всієї ціннісної структури або зачепити ії частково.

Способи відновлення самоефективності. Актуалізація у людини iï найвищої цінності через осягнення глибинного змісту та сенсу страждання; прийняття власних негативних станів як особистісних ресурсів; реконструкція наявних смислів чи побудова нових відповідно до змінених життєвих умов.

Ще одна причина зниження рівня самоефективності при переживанні втрати - неочікуваність стресового впливу, коли ситуація втрати виникає раптово, різко, несподівано, паралізуючи людину своєю неконтрольованою стихійністю, вводячи іії у стан шоку, розгубленості, без- 
діяльності, апатії. Тривале перебування в таких станах породжує ризик кристалізації образу втрати - укорінення образу втрати у свідомості людини, неможливість конструктивного опрацювання цієї втрати, іiі переінтерпретації та прийняття.

Ефективний спосіб відновлення самоефективності - сприяння задоволенню базових потреб особистості, зокрема потреби в безпеці, що позитивно впливає на стабілізацію психічного стану людини та відновлення іiі нормального функціонування. Забезпечення атмосфери спокою, мінімізація впливу будь-яких зовнішніх стресорів, релаксація усе це запускає процеси самовідновлення.

У разі надмірної фіксації на образі втрати, що з часом може соматизуватися в тілі у вигляді хвороби, необхідно звернутися по комплексну допомогу. Зокрема, спеціаліст може дати рекомендації щодо застосування тілесних практик для зняття напруження, відповідних дихальних і релаксаційних вправ. Коли ж напруженість і тривожність буде послаблено, можна перейти до більш складних технік роботи: роботи 3 переконаннями, пошуку сенсу, написання оновленої життєвої історії.

Ще однією причиною втрати життєвих ресурсів є неадекватна самооцінка, коли людині важко оцінити життєву ситуацію об'єктивно, без викривлень. Так, низька самооцінка посилює невпевненість у собі, зневіру щодо можливості виходу з проблемної ситуації, породжує сумніви щодо досягнення успіху; у разі ж завищеної самооцінки людина, навпаки, переоцінює свої можливості, не бажає приймати допомогу інших - через гордощі “я сам (сама)” прохання про допомогу видається їй чимось принизливим і немислимим.

Способи відновлення самоефективності. Робота над самооцінкою (аби вона стала адекватною), визначення рівня домагань людини, з'ясування ії наявних та потенційних ресурсів - усе це дасть змогу об'єктивувати реальну життєву ситуацію особистості, узгодити ії конфліктні сторони, провести верифікацію особистісних цілей, переосмислити базові цінності, відмовитися від запозичених, “модних" і “трендових", актуалізувати щось своє, унікальне, нове. У випадку низької самооцінки доречно практикувати мистецтво “малих кроків", що полягає в щоденній практиці самозвітування: хоча 65 хвилин перед сном виділяти для цілісного пригадування дня, що минув (усі події, вчинки, переживання, емоції, рішення, ідеї, дії), з обов'язковою умовою помітити чи знайти хоч щось, за що людина могла б себе похвалити, чим могла б пишатися, що б іiї надихнуло або приємно вразило, здивувало, підштовхнуло до дій. У випадку завищеної самооцінки, коли власні сили і ресурси значно переоцінені, людина в самостійній боротьбі із складною життєвою ситуацією ризикує стати ії жертвою через емоційне вигорання, фізичне та емоційне виснаження, неминучість розчарування та застрягання в ілюзіях. За таких умов корисною буде практика прохання про допомогу 
як щоденний ритуал терміном хоча б на тиждень (а краще - на місяць). Це дасть змогу змінити звичні способи взаємодії з оточенням, усвідомити переваги нових поведінкових практик через поєднання і долучення до потужного соціального ресурсу.

Ще однією важливою причиною зниження рівня самоефективності особистості є нефункціональні ресурси - наявні ресурси в життєвому просторі особистості, які вона не використовує з різних причин: не помічає через надмірну фіксацію на втраті, не усвідомлює, знецінює, вважає дріб'язковими, неважливими, надуманими або ж, навпаки, нереальними, недосяжними.

Способи відновлення самоефективності. Робота 3 ресурсами особистості: фізичними, матеріальними, соціальними, психологічними, духовними. Передусім людина має усвідомити всі наявні ресурси, відповівши на низку запитань: Що я маю на сьогодні? Що після втрати залишилося зі мною? Які в мене сильні сторони? Що я можу використати прямо зараз? Хто мене оточує? До кого я можу звернутися по допомогу саме зараз? Що я можу зробити прямо зараз? Наступним кроком буде визнання функціональності цих ресурсів у конкретній життєвій ситуації. Далі слід виділити найбільш значущі та цінні ресурси, обміркувати можливість їх застосування та інтеграції. Якщо ж наявних ресурсів, здатних допомогти людині в складній життєвій ситуації, недостатньо, потрібно шукати потенційні ресурси, подбати про забезпечення їх доступності та швидкості застосування.

Важливим ресурсом для підвищення рівня самоефективності особистості є досягнуті нею в минулому успішні результати. Активація спогадів про перемоги, реальний успішний досвід протистояння труднощам і випробуванням підвищує позитивні очікування особистості та активує їі віру у свої можливості. Моделювання яскравих образів успіху також дає змогу підвищити рівень самоефективності людини.

Важливим ресурсом для відновлення рівня самоефективності особистості є опосередковані переживання, коли людина завдяки досвідові успіху чи поразки інших людей може пережити щось подібне. Ефективними в цьому випадку можуть бути групи взаємодопомоги різного профілю (наприклад, для батьків, які втратили дитину). Група має сильний ефект співпереживання важкої події втрати, надає необхідну підтримку та активує в учасників процеси відновлення, пропонуючи різні способи розв'язання проблеми, ділиться успішним досвідом подолання криз, дає людині відчуття належності, надію, упевненість, що іiі розуміють, що вона не сама у своєму горі.

Не варто ігнорувати такий корисний ресурс, як словесне переконування, адже недаремно кажуть, що сила слова може як знищити, так і зцілити, надихнути, відродити до життя. Рівень самоефективності може значно підвищитися, якщо значуща для особистості людина 
запевнить їі в тому, що вона здатна успішно впоратися з конкретною ситуацією, що в неї вірять і не сумніваються в ії спроможності подолати труднощі і досягнути успіху.

Медійні технології відновлення самоефективності. Корисною є поступова, опосередкована, ненасильницька стимуляція внутрішньої активності людини при переживанні втрати за допомогою медійних засобів. Це може бути, наприклад, перегляд мотивувальних фільмів, відеосюжетів, телепроектів, що містять важливу інформацію і водночас ненав'язливо пропонують глядачеві альтернативні сценарії вирішення питання, пробуджують у людині бажання діяти - спочатку дистанційно, програючи новий сценарій у своїй уяві, а згодом і в реальності.

Ефективність таких способів впливу підтверджується невгасимим соціальним запитом на організацію відповідних соціальних медійних проектів на телебаченні, в радіоефірі. Зокрема, можемо згадати такі телепроекти, як “Герої не вмирають”, “Будемо жити”, “Захисник Вітчизни”, покликані ознайомити суспільство з реальними історіями людей, яких не зламала війна, розповісти про їхній подвиг. Це реальні історії героїв, які дивують, захоплюють, надихають, мотивують, відроджують віру в людей, змушують повірити в неможливе, пробуджують бажання діяти, боротися і перемагати всупереч усім труднощам. Такі способи впливу $є$ різновидом наративного підходу в роботі. Після перегляду реальних сюжетів людина приміряє свідомо або несвідомо ці ролі на себе, проговорює їх зі знайомими, програє у своїй уяві, що дає їй змогу розширити поле огляду своєї проблеми, побачити інші можливості, варіанти, сценарії, способи виходу зі складних життєвих ситуацій.

Висновки. Отже, розроблена стратегія відновлення самоефективності особистості поєднує три послідовні етапи роботи - діагностичний, організаційний, технологічний, кожен 3 яких відіграє важливу комплементарну роль у комплексній роботі над переживанням втрати та іiі можливими психологічними наслідками. Відновлення самоефективності особистості є стратегічно важливим напрямом соціально-психологічної реабілітації, ресурсом конструктивного переживання втрат спрямованим на підтримку і гармонізацію загальних показників фізичного й психологічного здоров'я людини.

\section{Список використаних джерел}

1. Шапошник, Д. О. (2011). Ресурси теорії самоефективності особистості у сучасній психології. Вісник Харківського начіонального університету, Серія “Психологія”, 937, 302-305.

2. Титаренко, Т. М. (2016). Личностное здоровье в условиях травматизации: поиск путей восстановления, Теория и практика психотерапии: Исследования. Теория. Практика, 3 (5), 7-13.

3. Титаренко, Т. М. (2016). Можливості підтримання та відновлення психологічного здоров'я особистості в умовах довготривалої травматизації. 
Особистість в умовах кризових викликів сучасності: матеріали методологічного семінару НАПН України (с. 42-51). Взято 3 http://lib.iitta.gov.ua/ 704987/.

4. Davis, C. G., \& Nolen-Hoeksema, S. (2001). Loss and meaning: How do people make sense of loss? American Behavioral Scientist, 44, 718-735.

5. Davis, C. G., Wortman, C. B., Lehman, D. R., \& Silver, R. C. (2000). Searching for meaning in loss: Are clinical assumptions correct? Death Studies, 24, 497540.

6. Bandura, A. (1977). Self-efficacy: Toward to unifying theory of behavioral change. Psychological review, 84 (2), 191-205.

7. Хьелл Л., \& Зиглер Д. (1997). Теории личности (основные положения, исследования и применение). Санкт-Петербург: Питер-Пресс.

\section{References}

1. Shaposhnyk, D. O. (2011). Resursy teorii samoefektyvnosti osobystosti u suchasnii psykholohii [Resources of the theory of self-efficacy of the individual in modern psychology] Visnyk Kharkivskoho natsionalnoho universytetu, Seriia "Psykholohiia”, 937, 302-305 (ukr).

2. Tytarenko, T. M. (2016). Lichnostnoye zdorovye v usloviyakh travmatizatsii: poisk putey vosstanovleniya [Personal health in conditions of traumatism: the search for ways of recovery], Teoriya i praktika psikhoterapii: Issledovaniya. Teoriya. Praktika, 3 (5), 7-13 (rus).

3. Tytarenko, T. M. (2016). Mozhlyvosti pidtrymannia ta vidnovlennia psykholohichnoho zdorovia osobystosti v umovakh dovhotryvaloi travmatyzatsii [Possibilities of maintenance and restoration of personality's psychological health in the conditions of long-term traumatization]. Osobystist $v$ umovakh kryzovykh vyklykiv suchasnosti: materialy metodolohichnoho seminaru NAPN Ukrainy (pp. 42-51). Retrieved from: http://lib.iitta.gov.ua/704987/. (ukr).

4. Davis, C. G., \& Nolen-Hoeksema, S. (2001). Loss and meaning: How do people make sense of loss? American Behavioral Scientist, 44, 718-735.

5. Davis, C. G., Wortman, C. B., Lehman, D. R., \& Silver, R. C. (2000). Searching for meaning in loss: Are clinical assumptions correct? Death Studies, 24, 497540.

6. Bandura, A. (1977). Self-efficacy: Toward to unifying theory of behavioral change. Psychological review, 84 (2), 191-205.

7. Hjelle, L., \& Ziegler D. (1997). Teorii lichnosti (osnovnyye polozheniya, issledovaniya i primeneniye) [Theories of personality (basic positions, research and application)] St. Petersburg: Piter-Press (rus).

(C) Мирончак К. В. 